\title{
Surrounding the Void: Samuel Beckett and Spain
}

\author{
José Francisco Fernández \\ Universidad de Almería, Spain
}

Copyright (c) 2014 by José Francisco Fernández. This text may be archived and redistributed both in electronic form and in hard copy, provided that the author and journal are properly cited and no fee is charged for access.

\begin{abstract}
A study of the relationship between Samuel Beckett and Spain poses some striking questions which are relevant in understanding the cultural inclinations of one of the most important dramatists of the 20th century. Beckett consciously abstained from having direct contact with Spanish culture and never visited Spain, despite showing an interest in the politics of the country at different periods of his life. As a result of this state of affairs a no-go area emerges which calls for a reconceptualization of Beckett's ideas on travel, politics and even his own country. This article tries to approach the matter of Beckett and Spain from different angles, in an attempt to achieve a full panoramic view. The opinions of one of Beckett's Spanish friends, Manolo Fandos, are recorded here for the first time.
\end{abstract}

Key Words. Samuel Beckett, Ireland, Spain, French language and civilization, Italian and German languages, Fernando Arrabal, Manolo Fandos.

Resumen. Cualquier estudio sobre la relación de Samuel Beckett con España tendría que enfrentarse a algunas preguntas muy llamativas cuyo planteamiento, no obstante, es necesario para comprender las inquietudes culturales de uno de los más importantes dramaturgos del siglo XX. Samuel Beckett, conscientemente, evitó viajar a España a pesar de mostrar interés, en distintos periodos de su vida, por los acontecimientos políticos de este país. A raíz de esta situación parece surgir un espacio vacío en torno a España, lo que invita a un replanteamiento de algunas de las ideas ya conocidas sobre el escritor irlandés: su opinión sobre los viajes, sobre política o sobre su propio país. Este artículo pretende acercarse a la cuestión de Beckett y España desde distintos ángulos, con el objeto de lograr una visión general del problema. Las declaraciones de uno de los amigos españoles de Samuel Beckett, el pintor Manolo Fandos, se recogen aquí por primera vez.

Palabras Clave. Samuel Beckett, Irlanda, España, idioma francés y civilización francesa, idiomas italiano y alemán, Fernando Arrabal, Manolo Fandos.

ESTRAGON: I'm going.

VLADIMIR: Help me up first. Then we'll go together.

ESTRAGON: You promise?

VLADIMIR: I swear it!

ESTRAGON: And we'll never come back?

VLADIMIR: Never!

ESTRAGON: We'll go to the Pyrenees.

VLADIMIR: Wherever you like.

ESTRAGON: I've always wanted to wander in the Pyrenees.

VLADIMIR: You'll wander in them.

(Samuel Beckett. Waiting for Godot)

ISSN 1699-311X 


\section{1.- Introduction}

Samuel Beckett never went to Spain. At least there are no records that indicate that he ever crossed the Pyrenees. There is nothing particularly remarkable in that, he did not go to many other countries, like Poland, Bulgaria or South Africa, to name but a few. What is striking is that, for many years, he seems to have been skirting Spain, making a huge circle around this southern Mediterranean country, so that, at the end of his life, he had established a kind of cordon sanitaire around the area and this requires an interpretation. He was born in Ireland (1906) and lived there in his youth. In his early manhood he went to France and Italy, lived in London, travelled to Germany, returning to France to live there until his death in 1989. He went back to Ireland, Britain and Germany at different periods of his life, flew once to the US, and he also went on holiday or stayed briefly in the former Yugoslavia, Switzerland, Holland, Austria, Italy, Sardinia, Greece, Malta, Tunisia, Morocco, Portugal and Madeira, marking in this way Spain a place that had to be avoided, a no-go area, with which no interaction seemed possible. I do not think that there is a single answer to the question of why Beckett did not visit Spain. The issue cannot therefore be addressed in a straightforward way, in a single arrow to the centre where the heart of the matter may lie. In what follows I will try to mimic Beckett and to go round the subject in a series of circles, making different approaches as the only possible way of handling the problem.

It should be stated at the outset that this article does not deal with the influence of Spanish literature in the work of Samuel Beckett. Although Spanish culture at large did not leave an indelible mark in his oeuvre (Fernández 2011), it is true that his readings of Spanish authors can be detected in some of his works. María José Carrera, for instance, has proved that Beckett was acquainted with Cervantes' Don Quijote (which he had read in French) and that this influence can be appreciated in Mercier and Camier (Carrera 2007: 150).

The focus of this essay will specifically be on the relationship of Beckett with Spain, his likely opinions and misgivings, in an attempt to explain the reason for his not visiting the country. It is interesting to note that at different periods of his life he could have easily made the journey.

As a young man he had devoted some time at studying the language ${ }^{1}$ and in October 1935 he thought of visiting the country (Pilling 2006: 54). Many years later, in September 1968, in order to recover from a long illness, he ventured the possibility of having a holiday in the Canary Islands, although in the end he and his wife Suzanne opted for Madeira (Knowlson 1997: 559-560). In the early 1960's he was invited for a visit by one of his Spanish friends, Manolo Fandos, and in 1985 the organisers of a festival of his work in Madrid also sent the cursory request for his presence at the event, but the frontier was never crossed.

\section{2.- Beckett and travel}

The truth is that, with the exception of his visit to New York in 1964, Beckett's travels were limited to a rather small region of the world. When he was an established author, from the mid-1950's onwards, he lived in Paris and had a cottage in the village of Ussy-SurMarne, not far from the French capital, where he retired when he needed solitude. He occasionally went to England or Germany for work and he took a holiday with his wife to a warmer climate from time to time, and that was it. He did not even travel much inside France. The last time he visited his native country was in March 1968, for a funeral. He was not the seasoned traveller that an international writer of roughly the same age, like Angus Wilson, certainly was, visiting many countries, giving talks and attending conferences. ${ }^{2}$

The lengthiest journey he ever made was to Germany for six months, from September 1936

1. Beckett famously translated several poems in Spanish for his Anthology of Mexican Poetry (1958) and it is known that he occasionally corrected the versions of his plays in Spanish.

2. Incidentally, it should be said that Angus Wilson held Beckett in the highest esteem and considered him to be one of the greatest contemporary writers. Wilson admitted having been influenced by Beckett, particularly in the drawing of his characters without the props of modern civilization: "Beckett's rigour has been a corrective to what I feel to be the rather false humanism which I inherited from E.M. Foster's novels, a humanism derived from one segment of middle-class civilisation and not from humanity in general" (Angus Wilson in McDowell 1983: 268). 
to April 1937. He went alone, visiting a number of cities, as he had the intention of studying German art in museums and galleries. He had the vague prospects of becoming an art critic and he thought that this pilgrimage would be instructive. What is known from his (still unpublished) German diaries is that he found it tiring and fastidious to move alone like a ghost in the rain, to sleep in uncomfortable lodgings and deal with the everyday problems of any tourist: where to eat and drink, where to urinate or how to pass the time without spending too much money (Knowlson 1997: 232). Beckett was frequently tired, had a terrible cold, and suffered a series of annoying ailments, such as boils and lumps in various parts of his body. $\mathrm{He}$ was also frequently depressed. Reading his letters from Germany is to witness the progress of a tortured soul, dragging his feet from place to place. For instance, on 28 November 1936 he wrote to his friend Tom McGreevy:

If only I felt more up to looking at things, but for the past week I am in rotten form, grippé I think, with the old herpes \& a slowly festering finger. I wanted to go to Bremen before leaving Hamburg, but the light is so frightful, and the constitution of the gallery there now so doubtful (I mean what pictures have they left hanging), \& my apathy so enormous, that I have not made the trip (Beckett 2009: 386).

It was not the first time he had been to Germany. He had visited his aunt Cissie and her family in Kassel six times from September 1928 to January 1932, a period that covers his stay in Paris as lecteur d'anglais at the École Normale Superieur and his stint as a lecturer in Modern Languages at TCD. A glimpse into the nature of those journeys can be gathered by the highly autobiographical novel that he wrote in 1932 (to be published three years after his death, in 1992), Dream of Fair to Middling Women. Here the protagonist, alter ego of Beckett himself, and the first of a long list of Beckettian heroes, Belacqua Shuah, does not enjoy a single moment of the journeys between the different places he visits (largely repeating the journeys Beckett made between Paris and Kassel). Travel for Belacqua is irksome, something to be endured stoically. Nothing here of the expected excitement of a youth travelling abroad:

At Ostend he secured a corner seat in a through horsebox to Wien and defended it for 29 hours against all comers. The last 599 kilometers on beer (terrible stuff!), and in a horsebox, not a corridor coach, which explains why he stepped hastily out of the train at the Westbahnhof and looked feverishly up and down the platform (Beckett 1992: 12).

Travelling, if we are to believe the experience of Belacqua in the novel, is to be exposed to bouts of diahorrea, to be suffocated to death in a litter on the boat back home, to have one's feet tormented by new boots (from memories of his visit to Italy in April 1927), or to wander penniless for three days and three nights before reaching the comforts of home. It is not surprising, therefore, that in his novel Mercier et Camier (written in 1946, published in 1970), a narrative by Beckett in which a journey is specifically at the centre of the action, the narrator celebrates the fact that the two protagonists do not leave familiar surroundings and do not venture out to foreign lands:

Physically it [their journey] was fairly easy going, without seas or frontiers to be crossed, through regions untormented on the whole, if desolate in parts. Mercier and Camier did not remove from home, they had that great good fortune. They did not have to face, with greater or less success, outlandish ways, tongues, laws, skies, foods, in surroundings little resembling those to which first childhood, then boyhood, then manhood had inured them (Beckett 2010: 7. My emphasis).

Mercier and Camier, the narrator says, had the good fortune to stay in the same area where they had lived all their lives, revealing on Beckett's part an intense dislike for travelling, a wariness for what a radical change may bring to the essential balance needed for other, more exhausting, internal journeys. ${ }^{3}$

\section{Beckett and Ireland.}

The relationship that Samuel Beckett had with his own country may provide some insights from which to consider his lack of interaction with Spain. As has been acknowledged by scholars in recent years, Beckett's connection with Ireland is enmeshed

3. An idea reinforced in the same novel: “... a feeble idea may be obtained of what awaits him too smart not to know better, better than to leave his black cell and that harmless lunacy, faint flicker every other age or so, the consciousness of being, of having being" (Beckett 2010: 67). 
in a tangle of complex responses which hinder a clear, well-defined and neat definition of this relationship. His family was part of the Protestant middle class that witnessed during the 1920s and 1930s how their position of influence had gradually been diminished by the coming to power of a new ruling class which imposed a set of political reforms clearly motivated by Catholicism and by the need to distance themselves from Britain. Protestants were not persecuted in the Irish Free State, but they ceased to be a relevant force in the new country and many of them left Ireland. Those who remained tried to live apart from their Catholic neighbours as a way of showing that they had formerly belonged to a privileged class.

Beckett did not feel at ease with this group to which he naturally belonged. The clearest example of his detachment was his sudden resignation from his post as a lecturer at one of the educational strongholds of the Protestant Ascendancy, Trinity College Dublin, although naturally his distaste for teaching played an important part in this decision. But he did not feel attracted to the increasingly narrow policies of the different governments that were in charge of the Irish Free State either. He deeply loathed the imposition of a strict moral code which affected public life, like the censorship of books or the banning of contraceptives. The cultural atmosphere was not congenial to his taste: he found Dublin literary circles provincial and backward. Unlike other Protestant writers, he did not feel that embracing ancient myths or supporting nationalism was an acceptable alternative in order to become fully Irish. Consequently, he had nothing to do with the reenactment of the Celtic past which had been in vogue at the turn of the century. In short, he felt estranged in his own country. This, together with his unstable professional future as a writer and his problems at home (in particular the difficult relationship with his mother) made him settle permanently in France in October 1937. In Paris he was part of a circle of avant-garde writers with a cosmopolitan outlook, deeply committed to their art, with the towering figure of James Joyce at its centre. That was his milieu, where he wanted to stay, away from the monotony and uniformity which was the norm in his native land and where he had felt suffocated.
However, Ireland did not vanish from his writing. The unresolved question of Ireland, his uncomfortable position as regards Irishness, took shape in the form of a ghostly presence in the background, disturbing voices heard by the characters, familiar landscapes blurred in the haze, musical turns of phrase, ambiguous comments, cryptic references to a troubled history. Beckett's work does not deal with Ireland, but Ireland is always there: "If there is no sense in which Ireland can be taken as a sufficient context for an understanding of Beckett's work ... nevertheless it seems clear that future accounts of Beckett's aesthetic development must come to terms with the enduring impact of his early filiations with Ireland" (Kennedy 2010: 1). Ireland, as it is reflected in his work, should be placed at the centre of opposing forces. Beckett should be given credit "as an avant-garde artist by means of the manner in which he engages with an Irish context in the very process of deflecting it" (Morin 2009: 161-2).

The most frequent scenario in which this inner conflict is represented in Beckett's narrative and drama has at its centre, characteristically, the wandering tramp. Beckett did not agree with the idealized picture of the tramp as portrayed by the writers of the Irish Literary Revival and chose to furnish his own vagrants with real characteristics: they suffer from hunger, cold, loneliness, madness, despair. What is more relevant in the interest of this paper, they are always wandering without getting anywhere. They are part of the land, they were born there, but they are not integrated into society, they have hardly any contact with anyone apart from other destitute characters. Mercier and Camier, Molloy or Vladimir and Estragon, among others, would be clear examples. Beckett had fond memories of the landscape near his house in the south suburbs of Dublin, where he used to walk with his father: the moors, the heather, the undulating hills, the sea at the distance... This is a recurrent picture, beautifully rendered in his prose, but the temporality of these descriptions, the fact that they are seen in transit, their fleeting quality, indicates their unstability as referents:

there is no 'formerly known' place, no prior world that used to make sense; rather, dating 
to the earliest days any aging narrator can recall, there is only repetitive motion across, and cyclically renewed and frustrated efforts to set narratives within, a tangible, real and affective ground that has never been comprehensible (Pearson 2010: 27).

According to Nels Pearson, the mixture of "concreteness and ambiguity, familiarity and disorientation" (2010: 33), would be the personal imprint given by Beckett to a familiar landscape, instilling in it his own fears and misgivings.

What is clear is that obsessional Ireland, as David Pattie (2010) calls it, was for Beckett an unfinished business, an unresolved problem, and there was perhaps no place for another landscape when the first one had not been fully apprehended. In any case Beckett's natural environment was the realm of culture, and here there were other horizons that vied to attract his attention and which occupied his mind for many years.

\section{Beckett and Other Cultures}

Against the cultural and social constraints at home, France, the country and its civilization, represented for Beckett his vital lifeline. His love for the French language started early, when he was an infant and his parents sent him to a kindergarten where he was taught French. Then, until the age of 13 he attended a school run by a French master. "As an Anglo-Irish child growing up in a genteel environment in the Dublin suburbs", French was a "veneer of sophistication" for his social class (Barry 2005: 505). He later studied French (and Italian) at university and during his short period as a lecturer he taught French literature. As has been said, he lived permanently in France from 1937 onwards. The start of the Second World War found him on a visit to Ireland and he urgently returned to France because he "preferred France in war to Ireland in peace" (Shenker 1979: 147). Although he had written only in English in his beginnings as a published author, it was when he changed to French in the mid1940s when he managed a breakthrough in his career, obtaining international recognition with En attendant Godot (1952). His life-long partner (and wife from 1961), Suzanne Deschevaux-Dumesnil, was French and they lived in Paris until their deaths. His admiration for French literature extended from classic as well private tuition on the language. authors (Rabelais, Ronsard, Racine) to modern ones (Marguerite Duras, Robbe-Grillet, Robert Pinget), with masters such as Flaubert, Verlaine, Rimbaud or Proust, occupying a prominent place in his education as a man of letters. "At length", writes Andrew Gibson, "he became as much French as he was Irish" (2010: 45).

Italian culture, too, exerted on him a powerful influence. His love for Dante and $L a$ Divina Commedia, lasted all his life: "Dante was his mentor" (Atik 2001: 79). But he also admired other, more contemporary Italian authors, Leopardi in particular. He had first studied Italian at university, receiving If "Italy could never advance any pretence of 'ownership' over Beckett”' (Caselly 2009: 210), it is true nevertheless that in Italian Beckett found a safe haven: "Italian [was], as we might say, 'less amusing', but more moving, more a matter of passion and feeling than of thinking" (Pilling 2009: 11).

If Italy retained for Samuel Beckett the romanticism of a love of youth, as he grew older German culture and language consolidated themselves as serious contenders for Beckett's affections. In the 1960s and 1970s he travelled sometimes to Germany to direct his plays and to work for TV. There was something in the style of German writing (Goethe, Heine, Schopenhauer) and in German music (Beethoven, Schumann, Brahms, the Austrian Schubert) that suited his personality, a subtle, sober way of approaching art and life:

The frustrated striving of the individual in a meaningless universe, preoccupations with melancholy, solitude and loss were themes Beckett found within this [German] tradition, and the dark and heavy, even tragic, quality of the German language coincided with feelings he was trying to come to terms with on a personal level and express in his own writing. (Nixon 2011: 9)

Considering the fullness provided by French, Italian and German languages and literatures, there was not perhaps for Beckett a pressing need to enter Spain, either geographically or culturally. An important factor to take into account in this respect is that Beckett did not have in his formative years a Spanish teacher whom he could look up to, someone who would have instilled in the young man the 
interest for the language, the country and its traditions. Walter Starkie, Professor of Spanish at TCD from 1926, certainly did not fulfil that role. Beckett "never liked [Starkie] well enough to treat badly" (Pilling 2009: 15). Starkie's populist instincts might have acted against a rapport with Beckett, who showed a haughty demeanour at this time. Besides, Starkie was a rival of Beckett's mentor at TCD, Professor Rudmose-Brown, and that would have prevented them strengthening the links, should the occasion had arisen.

A very close friend of Beckett, Ethna MacCarthy, a student of Spanish at TCD and with whom Beckett had fallen in love, was taught by Starkie and it is likely that one vulgar and obscene poem in Spanish that appears in Dream of Fair to Middling Women (Beckett 1992: 209) might have come across by way of Walter Starkie (Pilling 2004: 329). One of the characters in this early novel of Beckett's, the Alba, is based on Ethna MacCarthy and her utterances in Spanish consist mainly of vulgar expletives. The forcefulness of such expressions as "hijo de la puta blanca!", “carajo” (1992: 152), "trincapollas" (154) or "mamon"[sic] (171), which he put in the mouth of the Alba, suggests that at this stage Spanish for Beckett might be associated with the idea of a brutish, rough language, far from the subtleties of French or Italian. This takes us to the final part of this journey, to the territory (through the indirect contact of friends) that Beckett thought it better not to enter physically or emotionally.

\section{Beckett's Spanish Friends.}

Samuel Beckett had, at least, two very close Spanish friends: playwright Fernando Arrabal (born 1933) and painter Manuel Martí Fandos (known as Manolo Fandos, born 1928). The relationship of the two Spaniards with Beckett presents a number of similarities: both men met the Irish author in the late 1950s, when they were young, unexperienced newcomers in Paris. They were struggling to make a name for themselves with their art, and in both cases Samuel Beckett and his partner Suzanne Deschevaux-Dumesnil, felt protective about them, helping them in different ways. It makes sense that, apart from what he read in the newspapers and from other media, much of the information that Beckett obtained about Spain came from them. ${ }^{4}$

In 1956 Fernando Arrabal was a talented young man, with a wildly creative talent for the stage, and he was also physically weak. According to Arrabal, he met Beckett when he was in a sanatorium near Paris where he was recovering from tuberculosis (Arrabal 2009: 6). Beckett, who at this time was reluctantly riding the wave of success of En attendant Godot and who had undergone similar circumstances of poverty as those of young Arrabal, immediately took him under his wing and made him a sort of protegé, which meant that he followed his career closely and spoke warmly about him to publishers and friends. Although in different circumstances, Arrabal had left Spain for similar reasons to those that had impelled Beckett to abandon Ireland, namely, a suffocating cultural environment, lack of freedom and provincial attitude to the arts on the part of the authorities.

Beckett's concern for his friend was put to test in the summer of 1967. Arrabal had been promoting one of his books in a department store in Madrid when, while signing copies for readers, he wrote something for a young admirer that the authorities considered blasphemous. He was therefore arrested and taken to prison. The trial took place in September of that same year and because of the international pressure he was acquitted with only a fine imposed upon him. Many writers had spoken in his favour (François Mauriac, Jean Anouilh, Eugène Ionesco, etc.), signing a petition for his release. Samuel Beckett had offered to testify at the trial, although it was not

4. Beckett occasionally received visits from Spanish intellectuals, as it happened with theatre director Trino Martínez Trives in 1959 (all translations are mine): "I talk to him about Spain, about how difficult it is for his theatre to be performed commercially there. Beckett smiles" (Martínez Trives 1965: 40). ["Le hablo de España, de lo difícil que resulta que su teatro se represente comercialmente. Beckett sonríe"]. He also followed the news about Spain. From a conversation he had with Charles Juliet on 14 November 1975, it is obvious that Beckett kept up with what was happening in those days before the imminent death of the dictator Francisco Franco. Beckett is described explaining to his interlocutor the likely outcome of events if Franco were kept alive artificially (Juliet 2009: 34). 
necessary in the end. What he did was to write a letter to Arrabal's lawyer to be given to the judges of his case and which he allowed to be made public. The first lines of the letter are particularly relevant, for this is the only occasion in which Beckett wrote something specifically and unmistakably about Spain:

As it is impossible for me to testify in the trial of Fernando Arrabal, I write this letter in the hope that it will reach the court of justice and may help the court to appreciate the exceptionally human and artistic worth of the man to be judged. On trial is a Spanish writer who, in a mere ten years, has become a first-rank dramatist on the strength of a profoundly Spanish talent. Everywhere his work is represented, and it is represented everywhere, Spain is present. It is on this already praiseworthy career that I invite the members of the court to reflect before they deliver their verdict. (in Arrabal 2009: 7. My emphasis) ${ }^{5}$

It is obvious from these lines that Beckett recognised in Arrabal's work something quintessentially Spanish. In his friend's plays he saw the forces that ruled the Spanish character, and also perhaps the structures of power that had formed Spain's recent and tragic history. Beckett's ideas about Spain were probably reinforced in his mind through his friend's drama.

Critics (Serreau 1965; Torres Monreal 1986) have remarked how Spain has given shape to Arrabal's theatre. He himself has recognised in his theatre a cathartic impulse: he wrote to expel his own private ghosts, those of a boy in postwar Spain, who went through a rigid Catholic education in different schools, all of them run by religious orders. The country in the years after the Civil War, when Arrabal was a child, were marked by "a corrupt ruling class,

5. "Dans l'impossibilité où je me trouve de témoigner au procès de Fernando Arrabal j'ecris cette lettre en espérant qu'elle pourra être portée à la connaissance de la Cour et la rendre peut-être plus sensible à l'exceptionnelle valeur humaine et artistique de celui qu'elle va juger. Elle va juger un écrivain espagnol qui, dans le bref espace de dix ans, s'est hissé jusqu'au premier rang des dramaturges d'aujourd'hui, et cela par la force d'un talent profondément espagnol. Partout où l'on joue ses pièces, et on les joue partout, l'Espagne est là. C'est à ce passé déjà admirable que j'invite la Cour à réfléchir, avant de passer jugement". were marked by "a corrupt ruling class, a sanguinary army, a deaf clergy and, beneath, a starving peasantry" (Wolfers 1987: 8). Besides, his father, a military man who had not supported the rebels, had disappeared never to be seen again. He experienced at home the rule of a domineering mother in a situation that paralleled that of the country, with enforced censorship and repression. These features would later manifest themselves as obsessive elements in his theatre: "Catholic religion, above all after he had learnt his lessons of Catechism" writes his wife Luce Moreau, "deeply impressed his imagination for the solemn, bloody and funereal character of its rites and ceremonies" (Moreau 1979: 153)."

So this was the picture of Spain portrayed to Beckett when he saw his friend's early plays such as The Tricycle (1953), and Beckett's two favourite pieces by Arrabal (Knowlson 1997: 793), The Two Executioners (1956) and The Vehicle Graveyard (1957): the tension of dark forces that stood for repression, abuse of power and a cruel disdain for artistic talent and sensibility. Arrabal, nevertheless, wrapped all these topics in a carnavalesque attitude, producing chaotic, earthy, grotesque plays.

Manolo Fandos, for his part, did not have an intellectual relationship with Beckett, but had rather a purely amicable, warm and loyal friendship with the Irish writer. $\mathrm{He}$ was a penniless would-be painter when he arrived in Paris in 1957. For years he survived doing a number of small, unskilled jobs. In March 1960 Fandos was invited by a friend to see $L a$ derniere bande by Beckett and Lettre morte by Pinget at the Théâtre Récamier. He realized that one of the actors, Jean Martin (who had played Lucky in the premiere of En attendant Godot in 1953), actually lived in his same building. Fandos's companion introduced him to the actor and they became friends. One day they were walking leisurely along Boulevard St. Germain when Martin stopped to greet a lady. She enquired about Martin's friend and invited them to have a coffee. She was Suzanne Beckett

6. "La religión católica, sobre todo en el momento que aprendió las primeras nociones del catecismo, impresionó duraderamente su imaginación por el aspecto solemne, sangriento y fúnebre de sus ritos y sus ceremonias". 
and invited the two of them to have dinner at her flat. That is how Fandos met Beckett, not knowing who he was: "A long time later I realized the importance of the distinction which Suzanne, together with her husband, granted me at taking me in, because the couple lived somehow on the defensive in order to face the mob of snobs who hovered over them, something which reduced their circle of friends" (Fandos 2004: n.p.). ${ }^{7}$ From that moment on Samuel Beckett and his partner displayed "a protective affection" (Fandos 2013) towards the young man, giving him food, clothes and inviting him regularly for dinner at home or at a restaurant. In 1961 Manolo Fandos had his first individual exhibition in Paris. On the opening night the Becketts bought one of his paintings and invited him for dinner at La Coupole, a famous brasserie in Montparnasse, to celebrate the event. Beckett would ocassionally call in at his studio in the afternoons to see his new work and to talk about painting, both men not always sharing the same opinion: "He [Beckett] was obsessed by the austerity of expression and myself, a young, Mediterranean man was perhaps too ambitious in what I wanted to say and did not understand his views" (Fandos 2004: n.p.). ${ }^{8}$

In the mid-1960's Fandos was invited by a famous gallery to take them some of his paintings for the director to inspect. One night, while having dinner with the Becketts, he commented that he would need someone with a car to take the work. Beckett offered to take him and his paintings to the Galerie Maeght, despite Fandos's protest as he did not want to cause him any trouble. Beckett turned up one morning at the steering wheel of his Citroën $2 \mathrm{CV}$ and not only did he drive Fandos to the gallery but also carried some of his friend's paintings to the first floor. When the gallery

7. "Mucho tiempo después me di cuenta de la importancia con que Suzanne, junto a su marido, me distinguió al aceptarme de inmediato, ya que la pareja vivía un tanto 'a la defensiva' ante la marabunta esnobista que los acechaba, hecho que reducía su círculo de amistades".

8. "Él estaba obsesionado por la economía de medios en la expresión y yo, joven, mediterráneo y quizás demasiado ambicioso en el significado, no comprendía sus tesis". director, Aimé Maeght, saw the famous playwright going up the stairs with his burden he was "paralyzed with astonishment" (Fandos 2004: n.p.) and bought all the young man's work without discussing the price.

The young Spaniard repeatedly told Beckett that he simply had to visit the Prado Museum in Madrid, but Beckett said that he would not visit Spain as long as Franco was in power (Fandos, 2013). The painter, in fact, organized a journey to Barcelona to see Romanesque art and he invited Samuel and Suzanne. The writer, again, declined the invitation. In the end Fandos made the journey to Catalonia together with Suzanne, Jean Martin, and a friend of theirs, Marthe Gautier. $^{9}$

I had the opportunity of interviewing Manolo Fandos in his home town, Burriana, near Valencia, in 2013. I told him that in the 1960s and 1970s Beckett had visited some countries (Portugal, Morocco) where human rights were not respected at the time. Why his insistence on not visiting Spain? "You see", Fandos told me, "for French intellectuals Franco was very important as a symbol of repression. The Spanish Civil War had had a tremendous impact in France, people had followed the events of the war very closely. Franco had acquired a symbolic relevance" (Fandos 2013). And after Franco's death? According to Fandos, from the late 1970s onwards, Beckett did not much feel like travelling.

\section{6.- Conclusion}

There are a number of reasons that may explain why Samuel Beckett never breached the gap that separated him from Spain. Travelling, in the first place, was not something that he happily enjoyed and some youthful experiences in other countries had not been satisfactory enough to make of him an enthusiast

9. In the interview I had with him, Manolo Fandos, at 85 , did not remember the dates when this journey took place. He mentioned a famous exhibition of Romanesque Art that was taking place in Spain at the time and which they visited. In 1961 the Spanish government organized an international exhibition in Santiago de Compostela and Barcelona (Exposición Internacional de Arte Románico, July-October 1961) and it is possible that they went to Spain during those months. 
explorer of foreign places. Secondly, he had a problematic relationship with his own country, a vague and complex feeling of otherness as regards Irish landscapes might have negatively affected the adoption of a surrogate geographical environment. Thirdly, in the realm of culture, other horizons occupied his mind and perfectly filled his aspirations for emotional and intellectual advancement. Besides, for a number of reasons he did not have a proper training in Spanish during his school and university years.
What he learnt about Spain as an adult might have not been compatible with his ideas about public life. Furthermore, conditions of social control in Spain might have been similar, in an extreme form, to his own experiences in Ireland. Finally, there were political reasons for him not to visit the country due to the rule of a dictatorial regime. Spain, therefore, became for Beckett a no-place, a conscious gap in his life and writings, a territory that he preferred not to enter for being too distant for his taste, his interests and his art.

\section{Works Cited}

Arrabal, Fernando. 2009. "Beckett”. L'Atelier du Roman, 59 (September): 3-7.

Atik, Anne. 2001. How it Was. A Memoir of Samuel Beckett. London: Faber and Faber.

Barry, Elizabeth. 2005. "Translating Nationalism: Ireland, France and Military History in Beckett's Mercier et Camier". Irish Studies Review, 13-14 (November): 505-515.

Beckett, Samuel. 2010 (1970). Mercier and Camier. London: Faber and Faber.

Beckett, Samuel. 1992. Dream of Fair to Middling Women. Dublin: The Black Cat Press.

Beckett, Samuel. 2009. The Letters of Samuel Beckett 1929-1940, Martha Dow Fehsenfeld and Lois More Overbeck (eds.). Cambridge: Cambridge University Press.

Carrera, María José. 2007. “En un lugar della Mancha': Samuel Beckett's Reading of Don Quijote in the Whoroscope Notebook", in Dirk Van Hulle and Mark Nixon (eds.). Samuel Beckett Today/Aujourd'hui. "All Sturm and no Drang". Beckett and Romanticism. Beckett at Reading 2006. Amsterdam and New York: Rodopi, 145-159.

Caselli, Daniela. 2009. "Thinking of 'a Rhyme for "Euganean"': Beckett in Italy", in Mark Nixon and Matthew Feldman (eds.). The International Reception of Samuel Beckett. London and New York: Continuum, 209-233.

Fandos, Manolo. 2004. De lo Vivo a lo Pintado. Burriana: Fundación Fandos.

Fandos, Manolo. 2013. Personal interview (20 December).

Fernández, José Francisco. 2011. "Spanish Beckett", in María Losada Friend et al. (eds.). Irish Studies in Europe 3. Dreaming the Future. New Horizons/Old Barriers in 21st Century Ireland. Trier: WVT, 63-74.

Gibson, Andrew. 2010. Samuel Beckett. London: Reaktion Books.

Juliet, Charles. 2009. Conversations with Samuel Beckett and Bran Van Velde. Champaign and London: Dalkey Archive Press.

Kennedy, Seán. 2010. "Introduction: Ireland/Europe... Beckett/Beckett”, in Seán Kennedy (ed.). Beckett and Ireland. Cambridge: Cambridge University Press, 1-15.

Knowlson, James. 1997 (1996). Damned to Fame. The Life of Samuel Beckett. London: Bloomsbury.

Martínez Trives, Trino. 1965. "Retrato frustrado de Samuel Beckett". La última cinta. Acto sin Palabras, by Samuel Beckett. Barcelona: Aymá, 38-42.

McDowell, Frederick P. W. 1983. "An Interview with Angus Wilson”, in Kerry McSweeney (ed.). Diversity and Depth in Fiction. Selected Critical Writings of Angus Wilson. London: Secker and Warburg, 264-297.

Moreau, Luce. 1979. "Sudor, sangre, y lágrimas en el teatro de Fernando Arrabal", in Angel and Joan Berenguer (eds.). Fernando Arrabal. Madrid: Fundamentos, 147-175.

Morin, Emilie. 2009. Samuel Beckett and the Problem of Irishness. Houndmills, Basingstoke: Palgrave Macmillan.

Nixon, Mark. 2011. Samuel Beckett's German Diaries 1936-1937. London and New York: Continuum.

Pattie, David. 2010. "Beckett and Obsessional Ireland", in S. E. Gontarski (ed.). A Companion to Samuel Beckett. Chichester, West Sussex: Wiley-Blackwell, 182-195.

Pearson, Nels C. 2010. "Beckett's Cosmopolitan Ground". Irish University Review, 40.2: 20-41.

Pilling, John. 2004. A Companion to Dream of Fair to Middling Women. Tallahassee, FL: Journal of Beckett Studies Book.

Pilling, John. 2006. A Samuel Beckett Chronology. Houndmills: Palgrave. 
Pilling, John. 2009. "Beckett and Italian Literature (after Dante)", in Daniela Guardamagna and Rossana M. Sebellin (eds.). The Tragic Comedy of Samuel Beckett. Roma: Università degli Studi di Roma, 5-19.

Serreau, Geneviève. 1965. "Arrabal”. El cementerio de automóviles. Ciugrena. Los dos verdugos, by Fernando Arrabal. Madrid: Taurus, 15-22.

Shenker, Israel. 1979. "An Interview with Beckett" (The New York Times, 05.05.56), in Lawrence Graver and Raymond Federman (eds.). Samuel Beckett. The Critical Heritage. London: Routledge, 146-149.

Torres Monreal, Francisco. "Introducción”. Fando y Lis. Guernica. La bicicleta del condenado, by Fernando Arrabal. Madrid: Alianza Editorial, 7-25.

Wolfers, John. 1987. “Introduction”. The Face of Spain, by Gerald Brenan. London: Penguin, 7-8.

Received $20^{\text {th }}$ January 2014 Last version $27^{\text {th }}$ January 2014

José Francisco Fernández is Senior Lecturer in English literature at the University of Almería. His most recent work focuses on the narrative prose of Samuel Beckett and his reception in Spain. He has also translated two novels by Samuel Beckett, Sueño con mujeres que ni fu ni fa, together with Miguel Martínez Lage (Tusquets, 2011), and Mercier y Camier (Confluencias, 2013). 